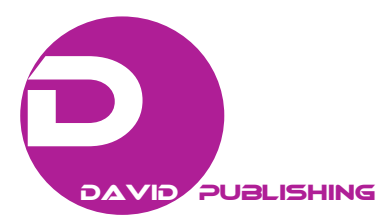

\title{
Management of Vitamin D Insufficiency in Young Children in the Russian Federation
}

Irina Zakharova ${ }^{1}$, Leonid Klimov², Stanislav Maltsev ${ }^{3}$, Svetlana Malyavskaya ${ }^{4}$, Olga Gromova ${ }^{5}$ Victoria Kuryaninova $^{2}$, Svetlana Dolbnya ${ }^{2}$, Anastasia Yagupova ${ }^{2}$, Anna Kasyanova ${ }^{2}$, Ekaterina Solovyeva ${ }^{1}$ and Ekaterina Koroleva $^{6}$

1. Department of Pediatric, FSBEI HPT "Russian Medical Academy of Postgraduate Continuing Education" of the Ministry of Health, Moscow 123995, Russia Federation

2. Department of Pediatric, FSBEI HE "Stavropol State Medical University” of the Ministry of Health, Stavropol 355002, Russia Federation

3. Department of Pediatric, FSBEI HPT “Kazan State Medical University Academy of Postgraduate Continuing Education” of the Ministry of Health, Kazan 420000, Russian Federation

4. Department of Pediatric, FSBEI HE "Northern State Medical University” of the Ministry of Health, Arkhangelsk 163000, Russia Federation

5. Department of Pharmacology, FSBEI HE “Ivanovo State Medical Academy” of the Ministry of Health, Ivanovo 153000, Russia Federation

6. Department of Pediatric, Clinic of Mother and Child, Moscow 125480, Russia Federation

\begin{abstract}
The paper presents the results of a multicenter study assessing efficacy and safety of a course-based regimen for hypovitaminosis D management in children under the age of three years. A dose of cholecalciferol was prescribed to children differentially, based on the baseline $25(\mathrm{OH}) \mathrm{D}$ levels. The dependence of the baseline vitamin $\mathrm{D}$ levels on the pre-test administration of cholecalciferol has been demonstrated. A high efficacy of the proposed management regimen in children, starting from the first 6 months of life, allows to widely recommend it in outpatient clinical practice. The level of calcidiol in children following one-month administration of 1000 to $4000 \mathrm{IU} /$ day increased from $23.7 \mathrm{ng} / \mathrm{ml}$ to $45.5 \mathrm{ng} / \mathrm{ml}(P<0.001)$, and the frequency of normal levels increased from $33.3 \%$ to $74.5 \%(P<0.001)$. The median increase in calcidiol levels following the one-month course of $1000 \mathrm{IU} / \mathrm{day}$, $2000 \mathrm{IU} /$ day, $3000 \mathrm{IU} /$ day, and $4000 \mathrm{IU} /$ day was $2.9 \mathrm{ng} / \mathrm{ml}, 22.3 \mathrm{ng} / \mathrm{ml}, 22.6 \mathrm{ng} / \mathrm{ml}$, and $32.0 \mathrm{ng} / \mathrm{ml}$, respectively. An increase in $25(\mathrm{OH}) \mathrm{D}$ levels closely correlates with the daily dose of cholecalciferol $(\mathrm{r}=0.504, P<0.001)$. The regimen proposed by the authors demonstrated, along with the efficacy, a high safety profile, the threshold limit of $100 \mathrm{ng} / \mathrm{ml}$ being exceeded only in $3.9 \%$ of children.
\end{abstract}

Key words: Young children, hypovitaminosis D, cholecalciferol, prevention, pharmaceutical management, course dose.

\section{Introduction}

Vitamin D deficiency is now recognized as one of the most important issues affecting the population health and is extensively investigated by specialists around the world [1-3]. The Russian pediatric school traditionally paid great attention to vitamin $\mathrm{D}$ research

Corresponding author: Zakharova Irina, MD, professor, research fields: vitamin $\mathrm{D}$, coeliac disease, food allergy, infant nutrition, anemia. throughout the XX century, developing a sufficiently effective and time-tested concept of prevention and treatment of rickets. At the same time, over the past 20 years, there has been a revolution in the notion of the so-called "noncalcemic" effects of vitamin D, which play an important role in the prevention of acute and chronic infectious and non-infectious human diseases [3-9].

The need to monitor levels of $25(\mathrm{OH}) \mathrm{D}$ from an early age in children is recognized in many countries. 
Universal criteria for children and adults have been developed for vitamin D levels $[5,10,11]$.

From the prenatal period, vitamin $\mathrm{D}$ plays a significant role in reducing the risk of abnormal pregnancy and its complications. A close relationship between the levels of $25(\mathrm{OH}) \mathrm{D}$ in the blood of pregnant women and umbilical blood of a newborn, effects of unfavorable antenatal history on a significant decline in vitamin D levels in children within the first months of life and the absence of a vitamin D depot has been proven [12-14].

In recent years, in various regions of Russia, changes in vitamin $\mathrm{D}$ levels in infants, the relationship between the feeding pattern and the risk of hypovitaminosis D have been analyzed in detail. This provided the evidence for the need in an increase in the prophylactic dose and advisability of year-round administration of cholecalciferol products to children throughout the Russian Federation [12-20].

Nevertheless, given the relatively low efficacy of prophylaxis of hypovitaminosis $\mathrm{D}$, the issue of implementing effective and safe strategies for management of vitamin $\mathrm{D}$ deficiency in various populations remains relevant. National, continental consensus and practical recommendations for prevention of hypovitaminosis D have been adopted and are implemented in North American (USA, Canada) and European countries [11, 22-27].

In accordance with the recommendations for prevention and treatment of vitamin D deficiency in Central Europe, the duration of the treatment course can be from 1 to 3 months, depending on the severity of hypovitaminosis $\mathrm{D}$. The monitoring of $25(\mathrm{OH}) \mathrm{D}$ levels is recommended 3-4 months after the end of administration of therapeutic doses, and then once every six months, especially if there are risk factors. In cases of severe deficiency, it is also advisable to monitor calcium levels, phosphate concentrations, and activity of alkaline phosphatase and calciuria levels [26].

The practice of prescribing vitamin D by Russian pediatricians for the prevention of rickets using cholecalciferol products, as a rule, only during the first year of life - in the age that is most vulnerable to the formation of bone deformities - undoubtedly results in a visible effect on the musculoskeletal system; however, the effect is only temporary, associated with the so-called calcemic effect of vitamin D.

At the same time, prolonged, so-called "noncalcemic" effects that determine its effect on the majority of body organs and tissues occur only at calcidiol concentrations of at least $30 \mathrm{ng} / \mathrm{ml}$, which can be achieved in the Russian Federation only by increasing the dose of cholecalciferol products. That is why the modern strategy of preventive medicine necessitates a lifelong daily administration of vitamin D.

A regimen for pharmaceutical management of hypovitaminosis D in children within the first three years of life has been developed using an aqueous solution of cholecalciferol as part of the National Program "Vitamin D Deficiency in Children and Adolescents in the Russian Federation: Current Approaches to Management".

The objective of the paper is to test the regimen for vitamin $\mathrm{D}$ deficiency management in young children in various regions of the Russian Federation depending on baseline calcidiol levels.

\section{Materials and Methods}

The analysis presented in this study was performed as part of a multicenter, prospective, uncontrolled cohort study conducted between November 2015 and December 2016 under a single protocol in Moscow $\left(55^{0} \mathrm{~N}\right)$, Arkhangelsk $\left(64^{0} \mathrm{~N}\right)$, Kazan $\left(55^{0} \mathrm{~N}\right)$ and Stavropol $\left(45^{0} \mathrm{~N}\right)$ (Fig. 1).

384 children aged from 1 month to 3 years were examined, of which $85(22.1 \%)$ children were aged from 1 to 6 months, $65(16.9 \%)$ children were aged from 6 to 12 months, 117 (30.5\%) children were aged from 1 to 2 years of life, 117 (30.5\%) children were aged from 2 to 3 years of life. 


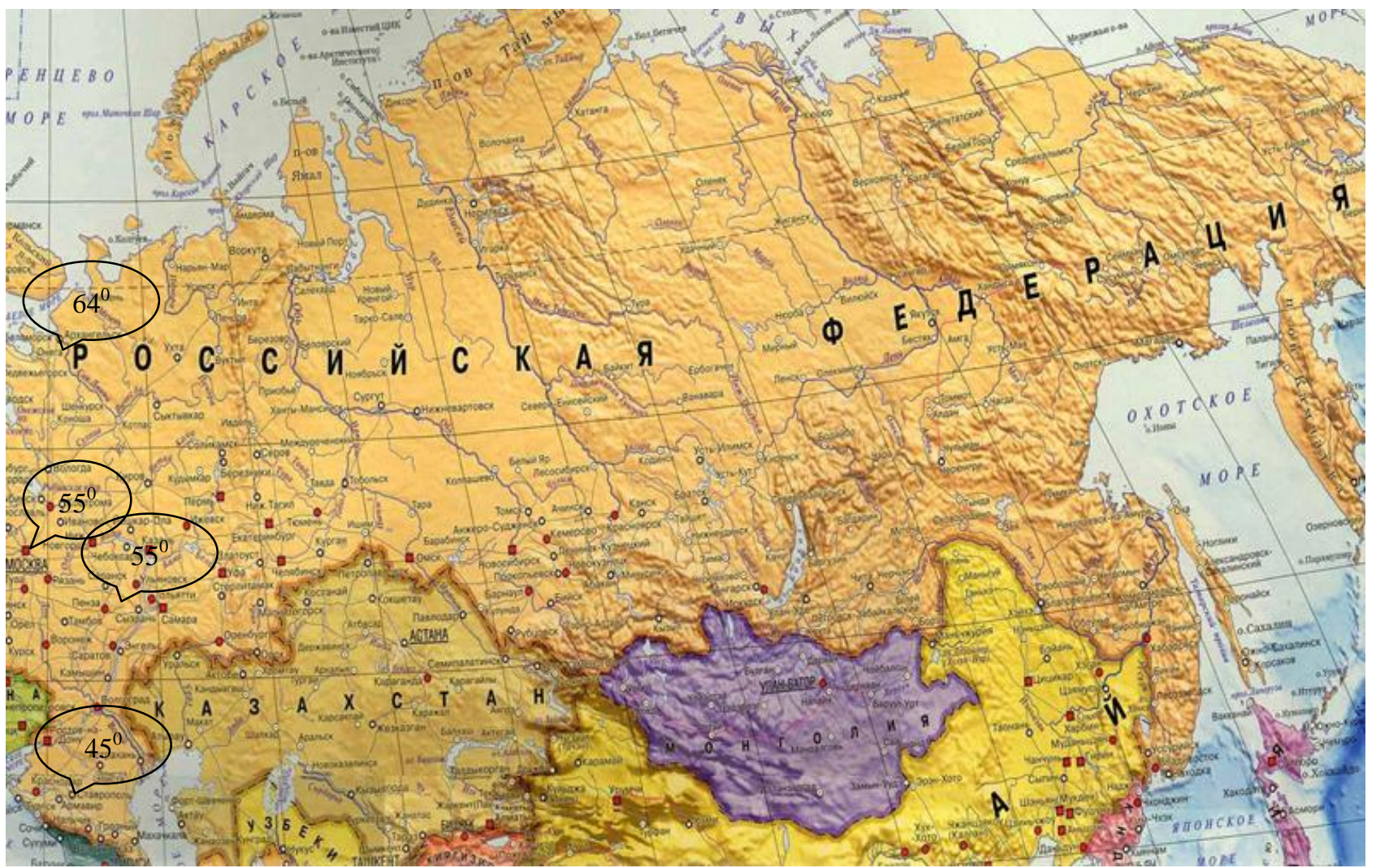

Fig. 1 Sites participating in the study in the Russian Federation.

The distribution of children under study was as follows: Moscow 68 (17.7\%), Arkhangelsk 99 (25.8\%), Kazan 113 (29.4\%), Stavropol 104 (27.1\%).

The study inclusion criteria were: age from 1 to 36 months, a satisfactory condition at the time of the study, the possibility of blood sampling, the consent of parents to participate in the study. The written informed consent was obtained from the parents of each child. The study protocol was approved by the Ethics Committee of the Federal State-Funded Educational Institution of Additional Vocational Education Russian Medical Academy of Continuing Postgraduate Education, Russian Ministry of Health.

Exclusion criteria: presence of any genetic syndromes and disorders of mental development, active rickets, hepatic and/or renal impairment, IUGR/grade 2 to 3 hypotrophy, malabsorption syndrome.

Determination of calcidiol levels in the serum by the competitive chemiluminescent immunoassay (CLIA) was performed at the laboratory of the EFiS scientific center in Moscow.

The results were interpreted in accordance with the recommendations of the International Society of Endocrinologists (2011): severe deficit: 25(OH)D levels less than $10 \mathrm{ng} / \mathrm{ml}$; deficiency: from 10 to 20 $\mathrm{ng} / \mathrm{ml}$; inadequate levels: 21 to $29 \mathrm{ng} / \mathrm{ml}$; normal levels: 30 to $100 \mathrm{ng} / \mathrm{ml}$, levels higher than $100 \mathrm{ng} / \mathrm{ml}$ were regarded as excessive, requiring adjustment of the vitamin D dose [1, 4, 5].

At the first stage, all examined patients were analyzed for the effect of the previous supplementation with cholecalciferol products on baseline calcidiol levels.

Among infants under one year of age, 70 (46.7\%) children were breastfed, 80 (53.3\%) children received adapted milk formulas. In the first year of life of 150 children, 105 (70.0\%) patients received prevention of rickets and vitamin D deficiency. Of 117 children aged 1 to 2 years, $60(51.3 \%)$ received vitamin D. Out of 117 children over the age of two years, only $23(19.7 \%)$ 
children received vitamin D. The dose of cholecalciferol products that patients received before the study initiation was $500 \mathrm{IU} /$ day in $83(44.1 \%)$ children, $1000 \mathrm{IU} /$ day in $76(40.4 \%)$ children and 1500 IU/day in 29 (15.4\%) children.

In order to simultaneously analyze the effect of the feeding type and supplementation with vitamin products on cholecalciferol levels, children under the age of 1 year were divided into separate subgroups (Fig. 2).

After determining the baseline vitamin D status, the study participants were prescribed cholecalciferol for 30 days. The daily dose of vitamin D was prescribed as follows: baseline serum 25(OH)D levels less than 10 $\mathrm{ng} / \mathrm{ml}-4000 \mathrm{IU} /$ day, 10 to $20 \mathrm{ng} / \mathrm{ml}$-3000 IU/day, 20 to $29 \mathrm{ng} / \mathrm{ml}-2000 \mathrm{IU} /$ day, more than $30 \mathrm{ng} / \mathrm{ml}$-a prophylactic dose of $1000 \mathrm{IU} /$ day.

Based on the results of 30-day administration of the aqueous vitamin D solution, a control laboratory test was conducted (Fig. 2). The aqueous cholecalciferol solution (500 IU per drop) was used as the vitamin D product.
The statistical analysis of the study results was carried out using the STATISTICA 10.0 software package (StatSoft Inc., USA). The Shapiro-Wilk test was used to determine the type of data distribution. For parametric quantitative data, the arithmetic mean (M) and the arithmetic mean error $(\mathrm{m})$ were determined. For nonparametric quantitative data, the median (Me) and quartiles [25Q-75Q] were determined.

In case of normal distribution, the Student's t-test was used to assess the intergroup differences in the analysis of quantitative parametric data. In case on non-normal distribution, the Mann-Whitney U test was used in groups with quantitative nonparametric data. In order to determine the statistical significance of the differences between qualitative data, the Pearson criterion $\left(\chi^{2}\right)$ corrected for small samples and the exact Fisher test (if one of the parameters was less than 4 and the total number of parameters was less than 30) were used. Pearson's (r) and Kendall's pair correlation coefficients were used to estimate the relationship between the parameters. Differences were considered statistically significant at $P \leq 0.05$ [28].

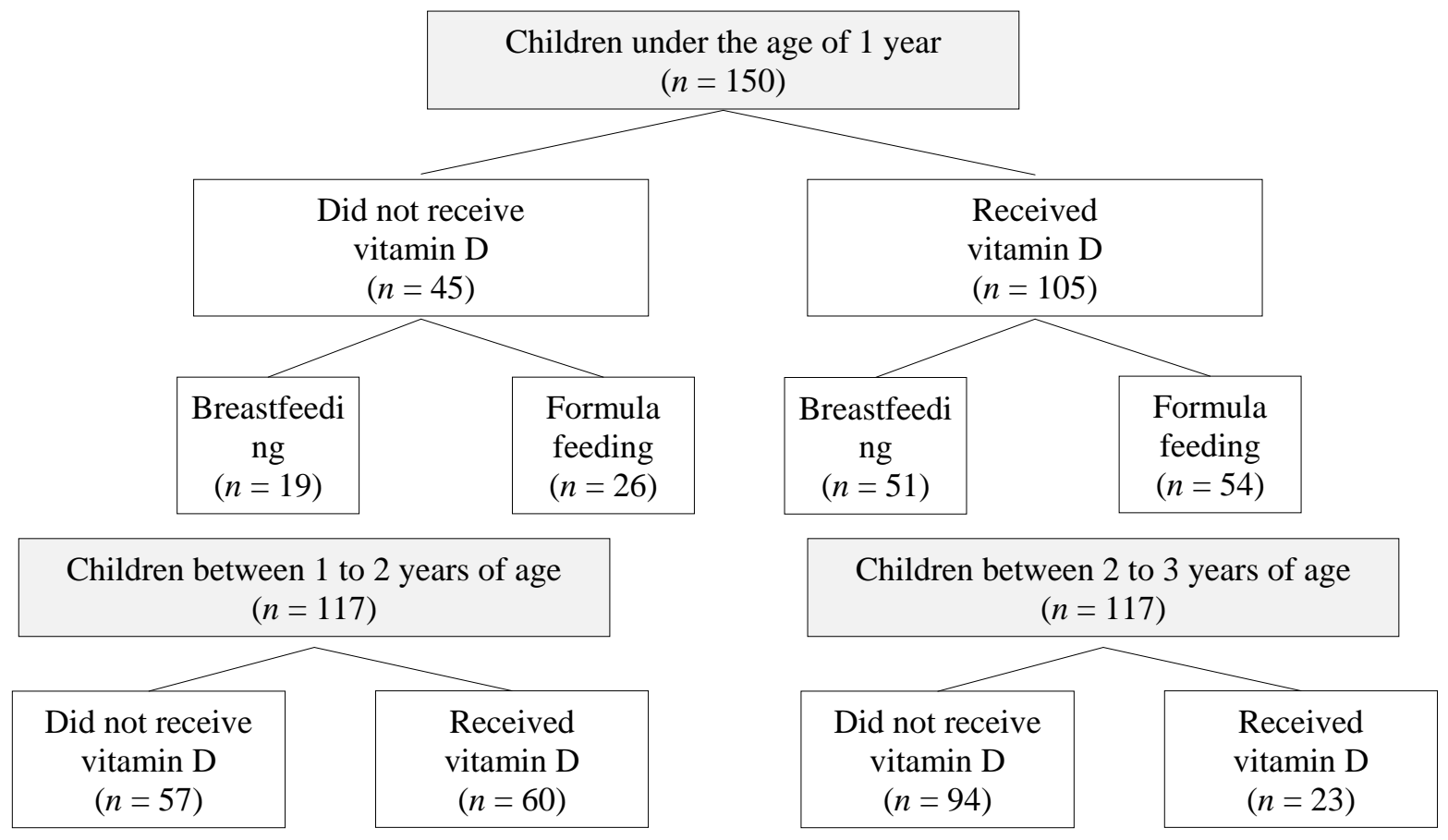

Fig. 2 Distribution of children by age, feeding type and baseline vitamin D intake. 


\section{Results and Discussion}

\subsection{Analysis of Baseline Vitamin D Levels in Young Children}

The baseline calcidiol level in young children in the Russian Federation that was the foundation for the therapeutic dose of cholecalciferol prescribed was 23.7 [13.8-34.9] ng/ml.

Severe vitamin D deficiency (less than $10 \mathrm{ng} / \mathrm{ml}$ ) was diagnosed in $58(15.1 \%)$ cases, vitamin $\mathrm{D}$ deficiency (10 to $19 \mathrm{ng} / \mathrm{ml}$ ) was detected in $101(26.3 \%)$ cases, inadequate vitamin D levels (20 to $29 \mathrm{ng} / \mathrm{Ml}$ ) were diagnosed in 97 (25.3\%) cases, and normal levels were found only in $128(33.3 \%)$ cases.

In the first 6 months of life, vitamin D levels in children in the Russian Federation were 25.8 [13.8-43.2] $\mathrm{ng} / \mathrm{ml}$, in the second 0.5 year of life, they were 33.9 [16.9-43.0] ng/ml, however, subsequently, starting from the age of 12 months, the levels steadily dropped to 24.1 [16.2-32.3] $\mathrm{ng} / \mathrm{ml}$ during the second year of life and only 18.4 [11.4-25.0] ng/ml during the third year of life. Obviously, in the first year of life, especially at the age of 6 to 12 months, most children, according to the recommendations of pediatricians, receive cholecalciferol supplementation, which determines relatively satisfactory vitamin D levels. During the second, and even more so, the third year of life, the number of children receiving vitamin $\mathrm{D}$ is significantly reduced, and this, in turn, is inevitably accompanied by a decrease in calcidiol levels and an increase in the number of children with vitamin D deficiency.

Fig. 3 shows the median of, and Fig. 4 shows the structure of baseline vitamin D levels in children at study sites.

Differences in vitamin D levels in various cities of Russia are not due to the geographical location and intensity of insolation, but are exclusively due to the frequency of prescribing cholecalciferol supplementation. While in Arkhangelsk, 79 children $(79.8 \%)$ received vitamin $\mathrm{D}$ at the time of analysis, 38 $(55.9 \%), 43(41.3 \%)$ and only $25(22.1 \%)$ children received vitamin D in Moscow, Stavropol, and Kazan. Nevertheless, even in Arkhangelsk, only 47 (47.4\%)

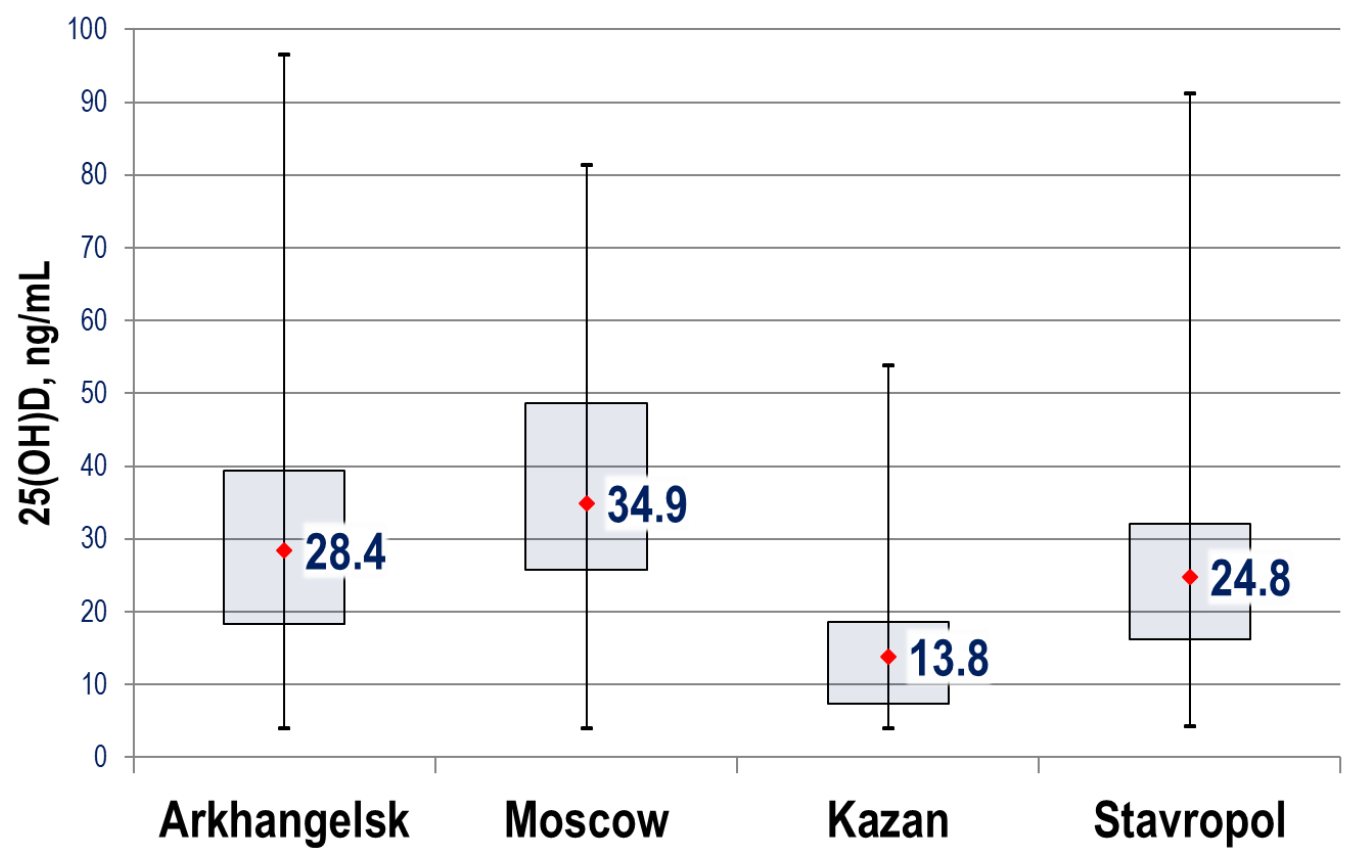

Fig. 3 Median baseline calcidiol levels in children in different cities. 

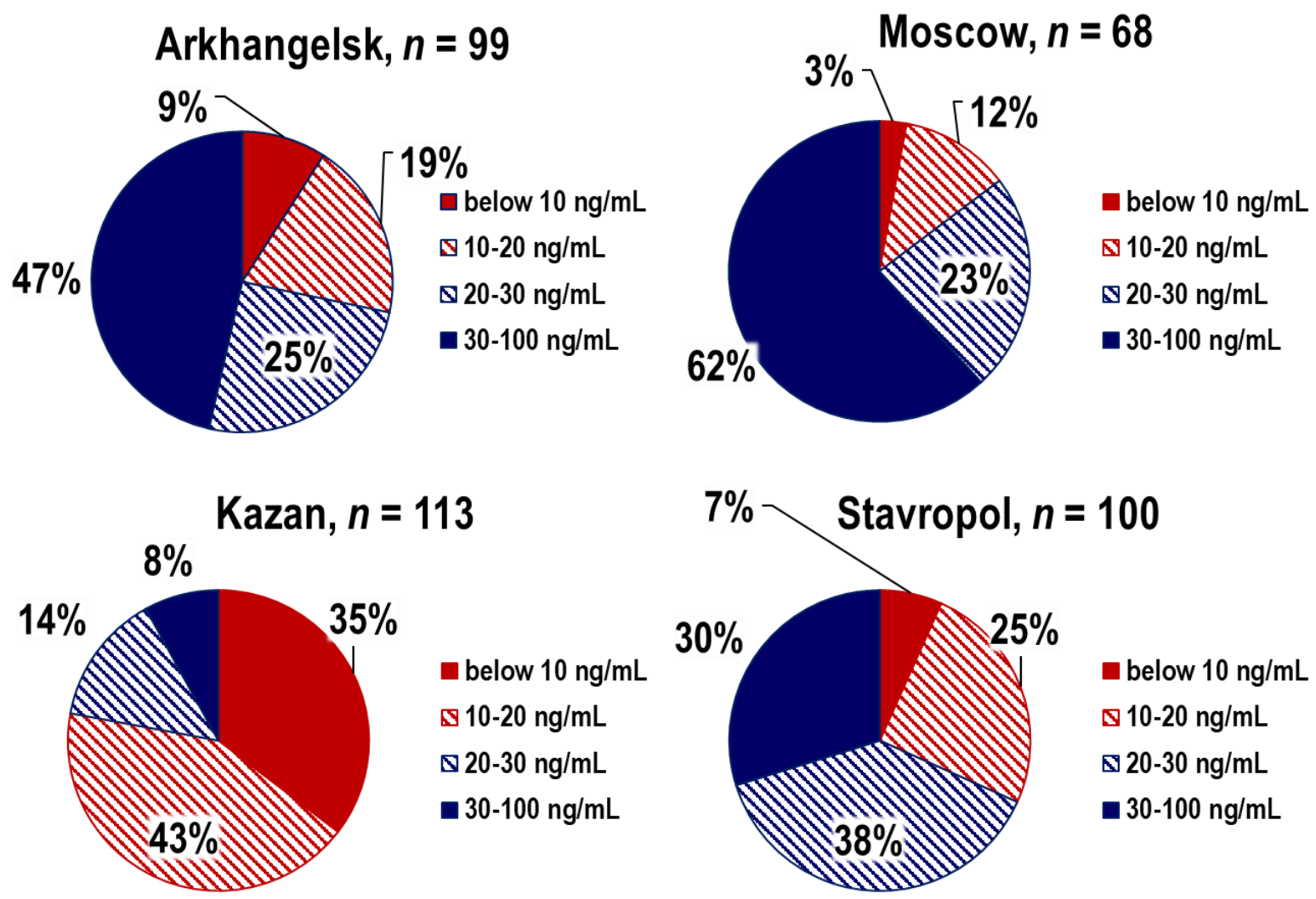

Fig. 4 The structure of baseline vitamin D levels in children at study sites.

Table 1 Calcidiol levels in young children based on administration of vitamin D products.

\begin{tabular}{llll}
\hline Children age & $\begin{array}{l}\text { Did not receive vitamin D } \\
\text { (IU) [25Q-75Q] }\end{array}$ & $\begin{array}{l}\text { Received vitamin D } \\
\text { (IU) [25Q-75Q] }\end{array}$ & $P$ \\
\hline 1 to 6 months breast-feeding & $9.4[4.1-15.3], n=16$ & $37.4[15.2-52.4], n=25$ & $<0.001$ \\
1 to 6 months formula feeding & $18.7[13.7-27.2], n=22$ & $47.3[31.6-58.0], n=22$ & $<0.001$ \\
6-12 months breast-feeding & $13.7[4.0-17.3], n=3$ & $35.5[28.9-46.8], n=26$ & $<0.001$ \\
6-12 months formula feeding & $25.2[18.6-35.1], n=4$ & $33.7[16.0-45.7], n=32$ & $<0.001$ \\
12-24 months & $20.6[10.8-24.8], n=57$ & $30.5[21.1-44.4], n=60$ & $<0.001$ \\
24-36 months & $16.8[10.6-23.0], n=94$ & $27.5[23.0-32.9], n=23$ & $<0.001$ \\
\hline
\end{tabular}

children had normal levels, $42(61.8 \%)$ and only 9 $(8.0 \%)$ of young children had normal levels in Moscow and Kazan, respectively.

Table 1 presents the results of a comparative analysis of the baseline determination of vitamin D levels based on previous administration of cholecalciferol products.

Based on the analysis of the data from Table 1, the following conclusions can be made: (1) neither exclusively breastfeeding nor formula feeding without dietary supplementation with cholecalciferol products allows to achieve adequate vitamin D levels in infants under one year of age; (2) there is a significant increase in calcidiol levels in all age groups in children receiving cholecalciferol products; (3) in children over one year of age, from 1 to 2 and especially 2 to 3 years of age, there is a significant decrease in $25(\mathrm{OH}) \mathrm{D}$ levels, while administration of preventive doses of cholecalciferol (500 IU/day) does not allow all children to achieve normal vitamin D levels.

Taking into account these preliminary findings, we developed and tested the management regimen for hypovitaminosis D in young children based on dosing of cholecalciferol preparations depending on serum 25(OH)D levels. 


\subsection{Efficacy of Hypovitaminosis D Management in Young Children}

The median calcidiol levels in the total group (384 children) following a one month course of therapy with cholecalciferol products increased from 23.7 [13.8-34.9] $\mathrm{ng} / \mathrm{ml}$ to $45.5[31.5-62.8] \mathrm{ng} / \mathrm{ml}(P<0.001)$.

Fig. 5 shows histograms of the $25(\mathrm{OH}) \mathrm{D}$ level distribution before and after one month administration of the aqueous vitamin D solution.

The analysis shows that while 25(OH)D levels did not exceed $30 \mathrm{ng} / \mathrm{ml}$ in $256(66.7 \%)$ children before cholecalciferol administration, the number of children with inadequate levels and deficiency decreased to 83 $(21.6 \%)(P<0.001)$. At the same time, the number of children with normal levels (30 to $100 \mathrm{ng} / \mathrm{ml}$ ) increased from $128(33.3 \%)$ to $286(74.5 \%)$ children $(P<0.001)$.

The number of children with severe deficiency (less than $10 \mathrm{ng} / \mathrm{ml}$ ), with deficiency (10 to $20 \mathrm{ng} / \mathrm{ml}$ ) and with inadequate levels decreased significantly from 58 $(15.1 \%)$ to $2(0.5 \%)$, from $101(26.3 \%)$ to $24(6.4 \%)$, from 97 (25.3\%) to 57 (14.8\%) children, respectively.

Following the course of pharmaceutical

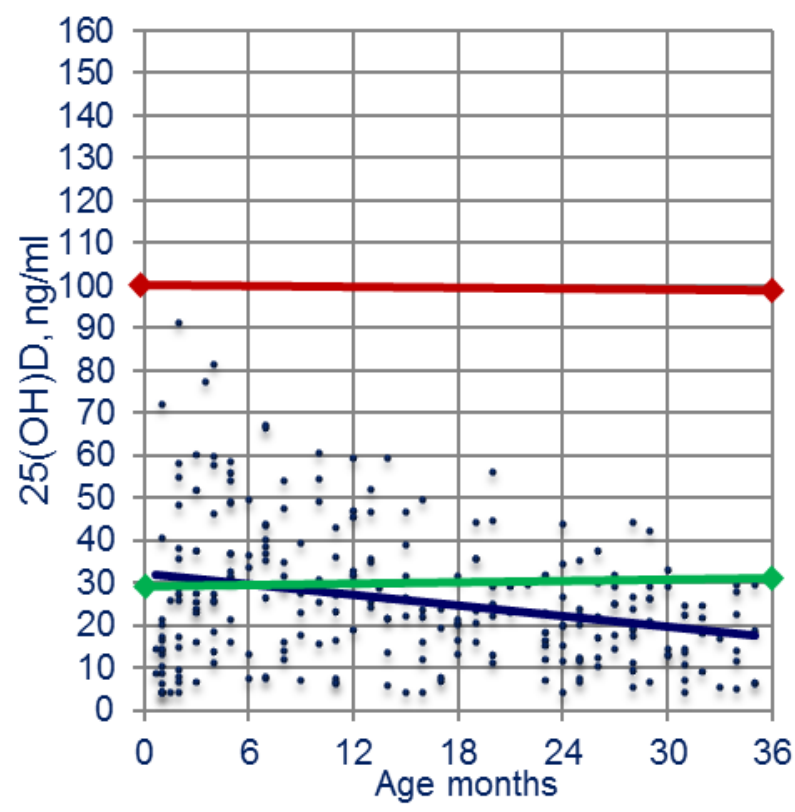

(A) management, the level of $100 \mathrm{ng} / \mathrm{ml}$ was exceeded in $15(3.9 \%)$ cases. In a detailed analysis of these cases, we noticed that $9(60.0 \%)$ of these children were under the age of 6 months, all were breastfed, and the baseline calcidiol levels generally were consistent with severe deficiency.

The average daily cholecalciferol dose for children under the age of 6 months, aged from 6 to 12 months, from 1 to 2 years and from 2 to 3 years was $2200.0 \pm$ $128.1 \mathrm{IU} /$ day, $1879.0 \pm 139.8 \mathrm{IU} /$ day, $2338.0 \pm 103.9$ IU/day, and $2718.0 \pm 83.4 \mathrm{IU} /$ day, respectively.

Fig. 6 shows changes in the calcidiol median in children following the proposed management regimen at each of the study sites.

At all the study sites, there were distinct unidirectional changes, with an increase in calcidiol levels ranging from $38.4 \%$ in Moscow to $131.9 \%$ in Kazan. In all cities, the $25(\mathrm{OH}) \mathrm{D}$ median following the one-month course exceeded the threshold value of 30 $\mathrm{ng} / \mathrm{ml}$ and was within the range of 30 to $50 \mathrm{ng} / \mathrm{ml}$, where, on the one hand, noncalcemic effects of vitamin D develop, and on the other hand, there is a minimal risk of overdose.

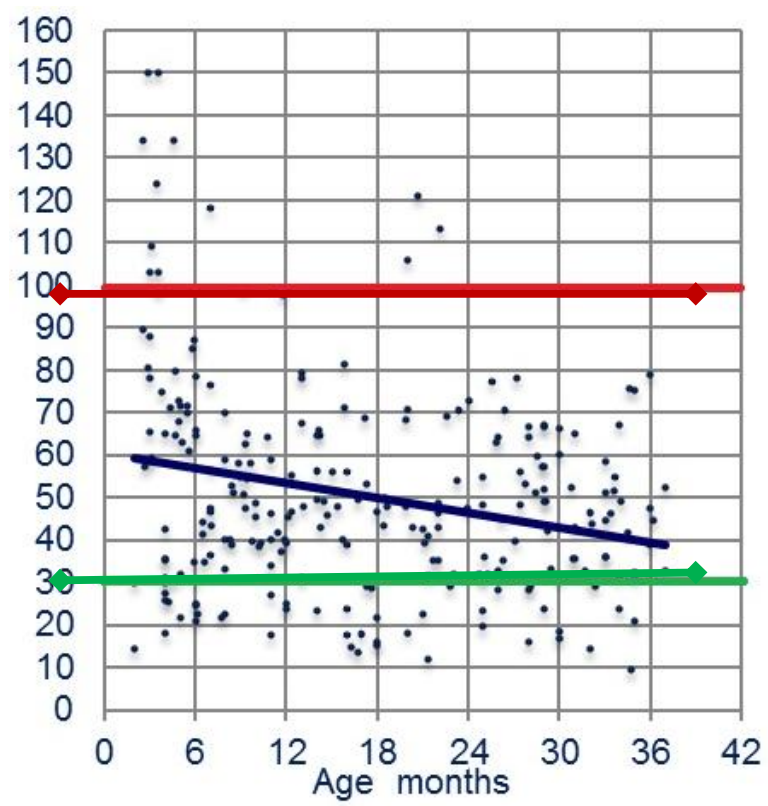

(B)

Fig. 5 Distribution of children by achieving $30 \mathrm{ng} / \mathrm{ml}$ levels before (A) and after (B) the course of cholecalciferol. 

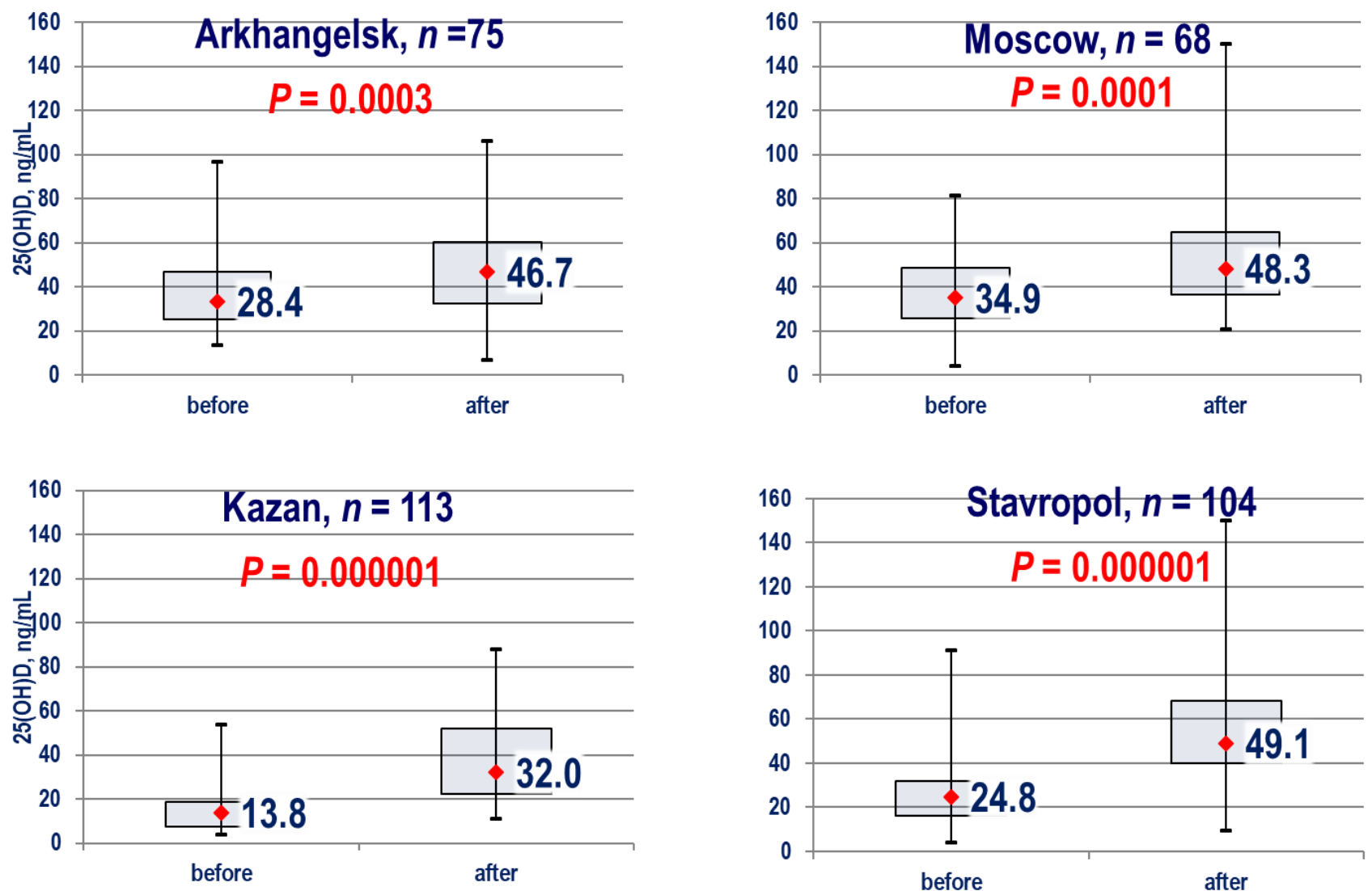

Fig. 6 Changes in 25(OH)D levels following the management course at study sites.

Table 2 shows the results of management with cholecalciferol products in children by age.

It is important that a significant increase in $25(\mathrm{OH}) \mathrm{D}$ levels was achieved in all age groups and exceeded the threshold value of $30 \mathrm{ng} / \mathrm{ml}$, being within an absolutely safe range in children of any age.

It is obvious that the regimen, where the therapeutic dose of cholecalciferol is based on the baseline calcidiol levels, allows to quickly and safely adjust vitamin D levels starting from the first months of life.

The analysis of the results presented in Table 3 demonstrates the dose-dependent effect of cholecalciferol products. In the general group, a negative increase in the calcidiol level was observed only in $65(16.9 \%)$ cases, with $56(86.2 \%)$ of these children receiving vitamin $\mathrm{D}$ at the dose of 1000 IU/day, only 9 (13.8\%) at the dose of 2000-3000 IU/day, while there was no negative increase in children receiving 4000 IU/day of cholecalciferol.
Following the use of $1000 \mathrm{IU} / \mathrm{day}$, the ratio of the frequency of positive and negative increase was only 1.3:1, while it was 18.2:1 $(P<0.001)$ and 19:1 $(P<$ 0.001 ) following the use of the therapeutic dose of $2000 \mathrm{IU} /$ day and the dose of $3000 \mathrm{IU} /$ day. During the management, it did not exceed $60 \mathrm{ng} / \mathrm{mL}$ in $287(90.0 \%)$ of 319 children with a positive increase, which completely excludes the achievement of $100 \mathrm{ng} / \mathrm{mL}$ level at the end of one-month course. Only 32 (8.3\%) children had a an increase in $25(\mathrm{OH}) \mathrm{D}$ levels that exceeded $60 \mathrm{ng} / \mathrm{mL}$ during the management course, and the daily dose of cholecalciferol was 3000-4000 IU in $26(81.3 \%)$ of these cases.

The median increase in calcidiol levels in young children following the one-month course of 1000 IU/day, $2000 \mathrm{IU} /$ day, $3000 \mathrm{IU} /$ day, and $4000 \mathrm{IU} /$ day was $2.9[9.4-12.9] \mathrm{ng} / \mathrm{ml}, 22.3[9.5-36.2] \mathrm{ng} / \mathrm{ml}, 22.6$ [11.6-43.6] ng/ml, and 32.0 [15.4-59.8) ng/ml, respectively. The correlation between the daily dose 
Table 2 Changes in calcidiol levels following cholecalciferol administration by age.

\begin{tabular}{llll}
\hline \multirow{2}{*}{ Children age } & \multicolumn{3}{c}{ IU 25(OH)D [25Q-75Q] } \\
\cline { 2 - 4 } & before management & after management & $<$ \\
\hline 1 to 6 months $(n=85)$ & $25.8[13.8-43.2]$ & $57.4[32.0-71.8]$ & $<0.001$ \\
6 to 12 months $(n=65)$ & $33.9[16.9-43.0]$ & $47.4[38.2-58.9]$ & $<0.001$ \\
$12-24$ months $(n=117)$ & $24.1[16.2-32.3]$ & $39.4[27.5-49.8]$ & $<0.001$ \\
$24-36$ months $(n=117)$ & $18.4[11.4-25.0]$ & $46.2[31.9-59.1]$ & $<0.001$ \\
\hline
\end{tabular}

Table 3 An increase in calcidiol levels following a one-month management course by the daily dose of cholecalciferol.

\begin{tabular}{llllll}
\hline Increase in & \multicolumn{5}{c}{ Daily cholecalciferol dose } \\
\cline { 2 - 5 } $25(\mathrm{OH}) \mathrm{D}$ levels & $\begin{array}{l}1000 \mathrm{IU} / \text { day, } \\
n=128\end{array}$ & $\begin{array}{l}2000 \mathrm{IU} / \mathrm{day}, \\
n=97\end{array}$ & $\begin{array}{l}3000 \mathrm{IU} / \mathrm{day}, \\
n=101\end{array}$ & $\begin{array}{l}\text { T000 IU/day, } \\
n=58\end{array}$ & $n=384$ \\
\hline negative & $56(43.8 \%)$ & $5(5.2 \%)$ & $4(4.0 \%)$ & - & $65(16.9 \%)$ \\
positive & $72(56.2 \%)$ & $92(94.8 \%)$ & $97(96.0 \%)$ & $58(100.0 \%$ & $319(83.1 \%)$ \\
0 to $20 \mathrm{ng} / \mathrm{mL}$ & $51(39.8 \%)$ & $38(39.2 \%)$ & $41(40.6 \%)$ & $20(34.5 \%)$ & $150(39.1 \%)$ \\
20 to $40 \mathrm{ng} / \mathrm{mL}$ & $18(14.1 \%)$ & $33(34.0 \%)$ & $25(24.8 \%)$ & $13(22.4 \%)$ & $89(23.2 \%)$ \\
40 to $60 \mathrm{ng} / \mathrm{mL}$ & $2(1.6 \%)$ & $16(16.5 \%)$ & $18(17.8 \%)$ & $12(20.7 \%)$ & $48(12.5 \%)$ \\
60 to $80 \mathrm{ng} / \mathrm{mL}$ & $1(0.8 \%)$ & $3(3.1 \%)$ & $5(5.0 \%)$ & $5(8.6 \%)$ & $14(3.6 \%)$ \\
over $80 \mathrm{ng} / \mathrm{mL}$ & - & $2(2.1 \%)$ & $8(7.9 \%)$ & $8(13.8 \%)$ & $18(4.7 \%)$ \\
\hline
\end{tabular}

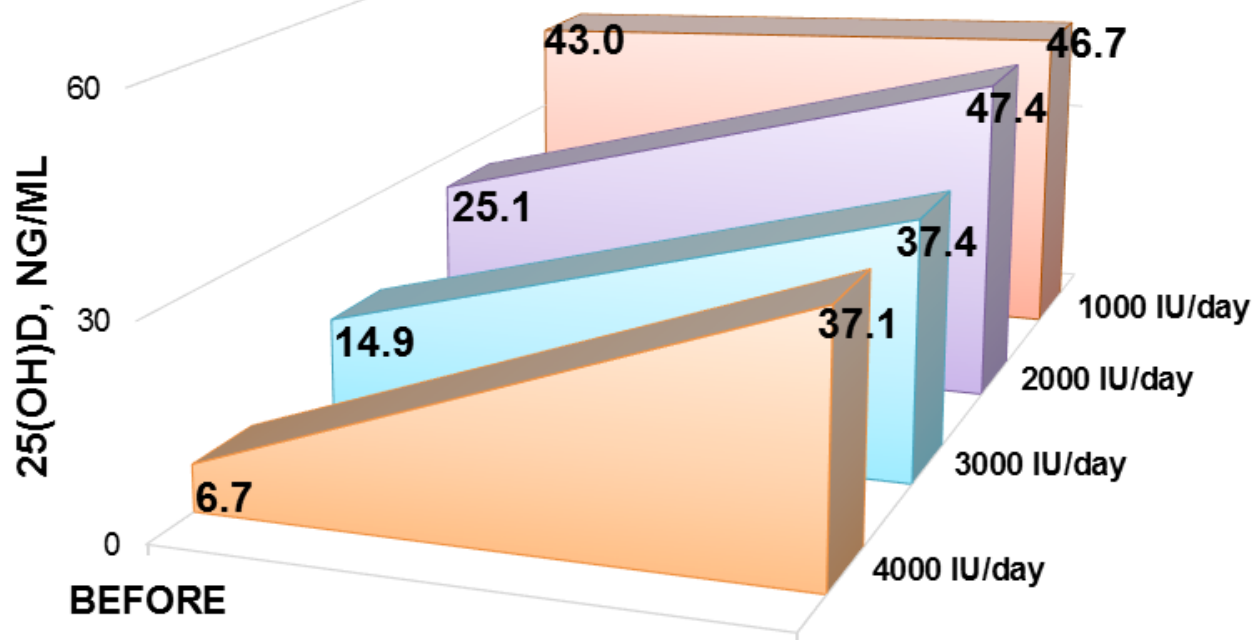

AFTER

Fig. 7 Changes in 25(OH)D levels following the management course by the dose of cholecalciferol.

and an increase in $25(\mathrm{OH}) \mathrm{D}$ levels following a one-month course of management with cholecalciferol was $r=0.504(P<0.001)$.

\section{Conclusions}

The majority of countries of the world have adopted programs for prevention and management of hypovitaminosis $\mathrm{D}$ in children and adults, while determination of calcidiol levels and evaluation of vitamin D levels as an integral component is included in the laboratory testing protocol for healthy people and patients with various conditions. 
We have conducted the detailed analysis that has demonstrated the high efficacy and sufficient safety of the proposed course of pharmaceutical management of vitamin D deficiency with cholecalciferol products in young children living in various regions of the Russian Federation.

In recent years, based on the results of large Russian multicenter studies, on the one hand, the necessity to increase the prophylactic dose of cholecalciferol in young children has been justified, and, on the other hand, a management regimen for hypovitaminosis D was developed, which in our opinion, will significantly reduce the frequency of vitamin $\mathrm{D}$ deficiency in children under the age of one year.

\section{References}

[1] Gromova, O. A., and Torshin, I. Y. 2015. Vitamin D. A Paradigm Shift / Ed. Acad. RAS E.I. Gusev, prof. I.N. Zakharova - Moscow: TORUS PRESS, 464.

[2] Holick, M. F., and Garabedian, M. 2011. "Vitamin D: Photobiology, Metabolism, Mechanism of Action, and Clinical Applications." Primer on the Metabolic Bone Diseases and Disorders of Mineral Metabolism, 6th ed. Washington, DC: American Society for Bone and Mineral Research, 129-37.

[3] Spirichev, V. B. 2011. "On Biological Effects of Vitamin.” D. Pediatrics. Journal n.a. G.N. Speransky 90 (6): 113-9.

[4] Shilin, D. E. 2010. "Vitamin-hormone D in the Clinic of the XXI Century: Pleiotropic Effects and Laboratory Evaluation (Lecture)." Clinical Laboratory Diagnosis (12): 17-23.

[5] Skripnikova, M. A., and Sorokin, M. Yu. 2012. "Diagnosis, Treatment and Prevention of Vitamin D Deficiency." Osteoporosis and Osteopathy (1): 34-7.

[6] Holick, M. F. 2012. "Vitamin D: Extraskeletal Health." Rheum. Dis. Clin. North Am. 5: 95-105.

[7] Gromova, O. A., Torshin, I. Yu., Uchaikin, V. A., and Limanova, O. A. 2014. "The Role of Vitamin D in the Maintenance of Anti-tuberculosis, Antiviral and General Anti-infectious Immunity." Infectious Diseases 12 (4): 65-74.

[8] Holick, M. F. 2007. "Vitamin D Deficiency." N. Engl. J. Med. 266-81.

[9] Grant, W. B. 2015. "The Role of Vitamin D Supplements in Treating Health Condition and Diseases Common among Those with Intellectual and/or Developmental Disabilities." Standardy Medyczne Pediatria. 12 (5):
775-80.

[10] Bischoff-Ferrari, H. A., Giovannucci, E., Willett, W. C., Dietrich, T., and Dawson-Huqhes, B. 2006. "Estimation of Optimal Serum Concentrations of 25-hydroxyvitamin D for Multiple Health Outcomes." Am. J. Clin. Nutr. 84 (1): 18-28.

[11] Holick, M. F., Binkley, N. C., Bischoff-Ferrari, H. A., Gordon, C. M., Hanley, D. A., Heaney, R. P., Murad, M. H., Weaver, C. M.; Endocrine Society. 2011. "Endocrine Society: Evaluation, Treatment, and Prevention of Vitamin D Deficiency: an Endocrine Society Clinical Practice Guideline." J Clin Endocrinol Metab 96 (12): 1911-30.

[12] Maltsev, S. V., Mansurova, G. S., Zakirova, E. N., and Vasilyeva, S. 2016. "The Role of Vitamin D in the Mother-placenta-fetus System.” Prakticheskaya Meditsina. 1 (93): 26-31.

[13] Klimov, L. Ya, Dolbnya, S. V., Kuryaninova, V. A., Alaverdyan, L. S., Kasyanova, A. N., Bobryshev, D. V., Bondar, T. P., Anisimov, G. S., and Abramskaya, L. M. 2015. "Vitamin D Levels in Newborns Children of Stavropol Region." Medical Bulletin of the North Caucasus 10 (2): 159-63.

[14] Zakharova, I. N., Klimov, L. Ya., Kuryaninova, V. A., Dolbnya, S. V., Maykova, I. D., Kasyanova, A. N., Anisimov, G. S., Bobryshev, D. V., and Evseeva, E. A. 2016. "Vitamin D Levels in Infants." The Russian Bulletin of Perinatology and Pediatrics 61 (6): 68-76.

[15] Gromova, O. A., Torshin, I. Yu., Zakharova, I. N., Spirichev, V. B., Limanova, O. A., Borovik, T. E., and Yatsyk, G. V. 2015. "On Vitamin D Dosing in Children and Adolescents." Issues of Current Paediatrics 14 (1): 38-47.

[16] Zakharova, I. N., Vasilieva, S. V., Dmitrieva, Yu. A., Mozzhukhina, M. V., and Evseeva, E. A. 2014. "Management of Vitamin D Deficiency." Effective Pharmacotherapy (3): 38-45.

[17] Klimov, L. Ya., Zakharova, I. N., Kuryaninova V. A., Dolbnya, S. V., Arutynyan, T. M., Kasyanova, A. N., Anisimov, G. S., Abramskaya, L. M., Borisova, Y. V., and Maykova, I. D. 2015. "Vitamin D Status in Children of the South of Russia in the Autumn-winter Period of the Year." Medical Advice 14: 14-9.

[18] Malyavskaya, S. I., Zakharova, I. N., Kostrova, G. N., Lebedev, A. V., Golysheva, E. V., Suranova, I. V., Maykova, I. D., and Evseeva, E. A. 2015. "Vitamin D Levels in the Population of Different age Groups Living in the City of Arkhangelsk." Issues of Current Paediatrics 14 (6): 681-5.

[19] Zakharova, I. N., Klimov, L. Ya., Kuryaninova, V. A. Gromova, O. A., Dolbnya, S. V., Kasyanova, A. N., Stoyan, M. V., Anisimov, G. S., Evseeva, E. A., Maykova, 
I. D., Koroleva, E. Y., Volodin, N. N., Zelinskaya, D. I., Cheburkin, A. A., and Holodova, I. N. 2016. "Efficacy of Prophylaxis of Hypovitaminosis D in Children Under One Year of Age: the Role of Feeding, the Effect of a Dose and Duration of Use of Cholecalciferol Products." Pediatrics. Journal n.a. G.N. Speransky 95 (6): 62-70.

[20] Malyavskya, S. I., Kostrova, G. N., Lebedev, A. V., and Golysheva, E. V. 2016. "Vitamin D Levels in Different Age Groups of the Population of Arkhangelsk." Human Ecology 12: 37-42.

[21] Zakharova, I. N., Gasilina, E. S., and Tyutyunik, L. P. 2015. "Vitamin and Microelement Levels in Children in the Autumn-winter Period." Pediatrics.Supplement to the Journal Consilium Medicum 3: 5-7.

[22] Charzewska, J., Chlebna-Sokol, D., and Chybicka, A. 2010. "Prophylaxis of Vitamin D Deficiency-Polish Recommendation 2009." Endokrynol Pol. 61: 228-32.

[23] Takacs, I., Benko, I., and Toldy, E. 2012. "Hungarian Consensus Regarding the Role of Vitamin D in the Prevention and Treatment of Diseases." Orv. Hetil. 153: 5-26.

[24] German Nutrition Society. 2012. "New Reference Values for Vitamin D." AnnNutr. Metab. 60: 214-46.

[25] IOM (Institute of Medicine). 2011. Dietary Reference Intakes for Calcium and Vitamin D. Washington (DC):
National Academies Press (US).

[26] Pludowski, P., Karczmarewicz, E., Bayer, M. Carter, G., Chlebna-Sokół, D., Czech-Kowalska, J., Dębski, R., Decsi, T., Dobrzańska, A., Franek, E., Głuszko, P., Grant, W. B., Holick, M. F., Yankovskaya, L., Konstantynowicz, J., Książyk, J. B., Księżopolska-Orłowska, K., Lewiński, A., Litwin, M., Lohner, S., Lorenc, R. S., Lukaszkiewicz, J., Marcinowska-Suchowierska, E., Milewicz, A., Misiorowski, W., Nowicki, M., Povoroznyuk, V., Rozentryt, P., Rudenka, E., Shoenfeld, Y., Socha, P., Solnica, B., Szalecki, M., Tałałaj, M., Varbiro, S., and Żmijewski, M. A. 2013. "Practical Guidelines for the Supplementation of Vitamin D and the Treatment of Deficits in Central Europe-Recommended Vitamin D Intakes in the General Population and Groups at Risk of Vitamin D Deficiency." Endokrynol. Pol. 64 (4): 319-27.

[27] Pludowski, P., Holick, M. F., Grant, W. B., Konstantynowicz, J., Mascarenhas, M. R., Haq, A., Povoroznyuk, V., Balatska, N., Barbosa, A. P., Karonova, T., Rudenka, E., Misiorowski, W., Zakharova, I., Rudenka, A., Lukaszkiewicz, J., Marcinowska-Suchowierska, E., Laszcz, N., Abramowicz, P., Bhattoa, H. P., and Wimalawansa, S. J. 2017. "Vitamin D Supplementation Guidelines.” J. Steroid Biochem. Mol. Biol. Feb 12.

[28] Glants, S. 1998. Medico-Biological Statistics. M.: Practice. 